\title{
DOKÁŽE MIKROMORFOLOGIE V ARCHEOLOGICKÉM KONTEXTU ODPOVĚDĚT NA OTÁZKU VYUŽITÍ ZAHLOUBENÝCH PROSTOR VE STŘEDOVĚKÉ VESNICI? PŘÍKLADOVÁ STUDIE BRNO-KRÁLOVO POLE
}

\author{
LENKA LISÁ - VÁCLAV KOLǍ̌ÍK
}

\begin{abstract}
Abstrakt: Problematika zahloubených suterénů je v literatuře diskutována předevšim z hlediska jejich funkce. Prezentovaný objekt datovaný do druhé poloviny 13. až první poloviny 14. století interpretujeme jako drobný sklipek, sloužici $k$ uskladněni potravin a nápojů $k$ denni spotřebě, a v pưvodni dispozici nadzemnich částí dřevohliněného domu předpokládáme i blizkost kuchyně, respektive v této době spíše prostoru určeného $k$ vaření. Z hlediska mikromorfologického studia podlahová vrstva na bázi sklípku vznikala po generace postupným našlapáváním a pravděpodobně i cileným zametáním. V kontextu s archeologickou interpretací reprezentuje podlahu sklípku, který byl ovšem záměrně udržován v relativní čistotě a na jehož podlahu byl opakovaně našlapáván běžný odpad z činnosti domácnosti. V tomto př́padě jde o první mikromorfologickou studii v kontextu předměstské vesnické usedlosti na našem území.
\end{abstract}

Klíčová slova: geoarcheologie - dřevohliněná zástavba-zahloubené stavby-formační procesy-podlahové horizonty.

Can micromorphology in archaeological contexts answer the question of the use of sunken spaces in medieval villages? A Brno - Královo Pole case study

\begin{abstract}
The issue of sunken cellars is mainly discussed in specialist literature from the perspective of their function. The presented feature dated to the period between the second half of the 13th century and the first half of the 14th century is interpreted as a small cellar storing foods and liquids of daily use. The original disposition of the overground sections of a wood and earth house presumably involved a kitchen, or rather, a space designed for cooking. In terms of micromorphological study, the floor layer of the cellar took shape over generations, by multiple treading and probably also deliberate sweeping. In the context with an archaeological interpretation it represents the floor of a cellar which was kept relatively clean and its floor was repeatedly covered in hardpacked household waste. The article is thus the first micromorphological study in the context of a suburban village homestead in the Czech territory.
\end{abstract}

Key words: geoarchaeology - wood and earth construction - sunken features - formation processes - floor horizons.

\section{1 Úvod}

Mikromorfologie v archeologickém kontextu je metoda, díky níž je možné detailně studovat sedimentární záznam a interpretovat jej v souvislosti s archeologickými nálezy (Macphail-Goldberg 2018; Karkanas-Goldberg 2019). V principu jde o mikroskopické studium zhruba 30 mikrometrů tenkých průřezů sedimentární matrix nalepené na zmatované sklíčko. Toto studium je prováděno v binokulárním mikroskopu při dvoj- až osminásobném zvětšení a následně v polarizačním mikroskopu při zvětšeních osm- až osmsetkrát (Stoops 2003). Díky takto detailnímu studiu lze identifikovat množství a tvary pórů vypovídající o procesech při a po sedimentaci, minerální složení sedimentu reflektující provenienci, organogenní a organominerální př́měsi, které většinou odrážejí činnosti spojené s přítomností člověka, a v neposlední řadě také pedogenní prvky, které jsou neocenitelným vodítkem při dedukci jak primárních, tak především sekundárních procesů vedoucích ke vzniku finálního sedimentárního záznamu (Stoops et al. 2010).

V kontextu středověké archeologie byla mikromorfologie mnohokráte použita jako neocenitelný zdroj informací pro studium podlahových úrovní (souhrnně Macphail-Goldberg 2018; Nicosia-Stoops 2017). V našem prostředí byla pro podobné situace mikromorfologie poprvé použita při studiu částečně zahloubené zděné komory raně novověkého domu v Tišnově u Brna (Lisá et al. 2009), v př́ípadě hodnocení výplní raně středověkých zemnic v Roztokách u Prahy 
(Novák et al. 2012; Kuna et al. 2013), raně středověké kovárny v Modřicích u Brna (Beran et al. 2013), zásobnice na parcele hotelu Padowetz v ulici Bašty v Brně (Lisá et al. 2017) nebo při studiu novověkých a recentních podlah v Dolním Němčí na Uherskohradišt'sku (Lisá-Lisý 2019; Lisá-Kočár et al. 2020). Zatím poslední práce tohoto typu je věnována problematice nadzemních částí domů ve středověkém Brně na příkladu výzkumu ve Veselé ulici (Lisá-Staněk et al. 2020). Cílem uvedených studií byla většinou snaha detekovat formační procesy vedoucí ke vzniku více podlahových horizontů. Otázkou zůstává, nakolik jsou vrstvičky nebo řekněme tenké horizonty, se kterými se setkáváme $\mathrm{v}$ archeologických výzkumech, opravdu nášlapovými horizonty podlah, nebo zda jde o nějaké př́ípravné fáze podlah či pozůstatky např́klad organického materiálu, který byl na podlaze deponován nebo kterým byla podlaha zpevňována.

Předkládaná studie se pokouší na příkladu laminovaného pochozího horizontu na dně menšího sklípku ukázat, jaký charakter a podobu má potenciální podlahový horizont a jak v daném kontextu pravděpodobně vznikl. Zároveň je v této studii diskutován pohled terénní archeologie $\mathrm{v}$ porovnání $\mathrm{s}$ dosavadními poznatky mikromorfologie o informačním potenciálu hliněných podlah.

\section{Historicko-archeologický exkurz k výzkumu Rezidence Mojmírovo náměstí v Brně - Králově Poli}

Záchranný archeologický výzkum byl vyvolán přípravou stavby „Rezidence Mojmírovo náměstí“. Sledovaný prostor se nachází na katastrálním území Královo Pole, při východní frontě Mojmírova náměstí (obr. 1). Východní hranici pozemku tvoří Košinova ulice (parc. č. 975, 976, 977/1, 977/2, 978/1, 978/2, 978/3; dnes celé jako parcela 977/2). Na zkoumaných parcelách se nacházely domy čp. 70 a 71 (Mojmírovo nám. č. o. 6, 7; dnes čp. 3105). Z historického hlediska byl prostor od vrcholného středověku součástí intravilánu historické vsi Královo Pole (náves na půdoryse dnešního Mojmírova náměstí).

Geomorfologicky se dnes zkoumaný prostor nachází v nadmořské výšce 218,00-221,50 m n. m., na mírném svahu, který pozvolna klesá východním směrem do inundace Ponávky. Svrchní část geologického podloží je tvořena kvartérní sprašovou návějí z posledního glaciálu. Na sprašové podloží nasedá holocenní půda tvořená černohnědou humózní hlínou, tzv. černozemí. Okolí lokality se nachází v oblasti tzv. brněnského masivu, konkrétně v jeho západním pásmu, pro které je

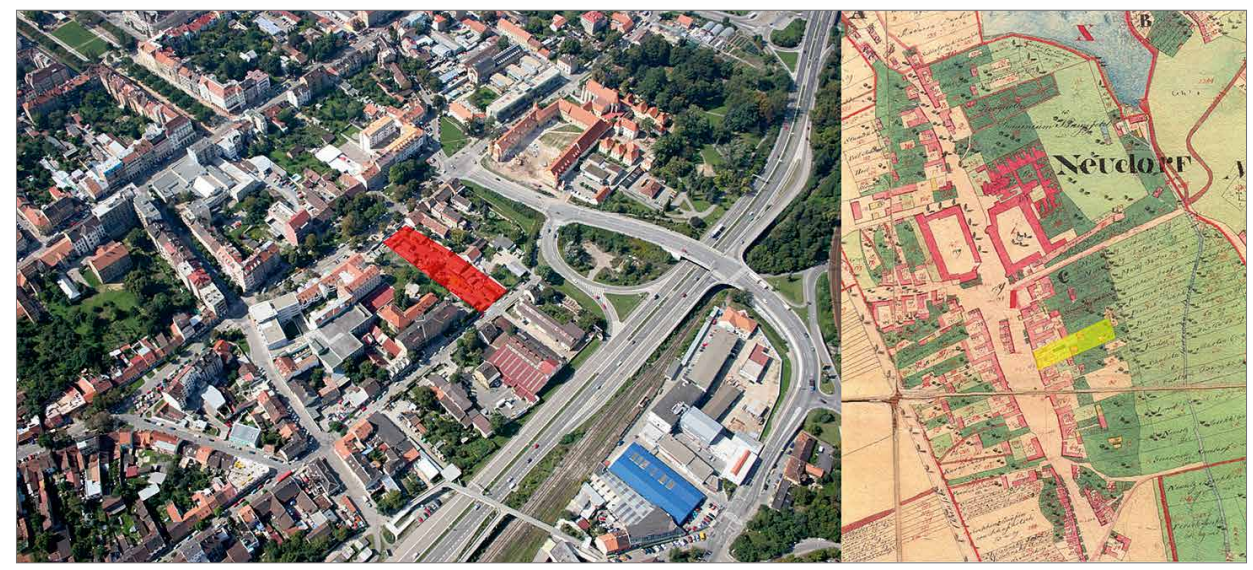

Obr. 1. A - lokalizace výzkumu v současné zástavbě Králova Pole; letecký pohled od jihovýchodu z archivu Archaia Brno z. ú.; B - plocha výzkumu na katastrálním plánu z poloviny 19. století.

Abb. 1. A - Lokalisierung der Grabung in der gegenwärtigen Bebauung von Královo Pole; Luftansicht von Südosten aus dem Archiv des eingetragenen Instituts Archaia Brno; B - Grabungsfläche auf einem Katasterplan von Mitte des 19. Jahrhunderts. 
typický výskyt granitů, granodioritů a dioritů (výchozy na protilehlém břehu Ponávky). Báze při bagrování stavební jámy odkrytého geologického profilu byla reprezentována terciérními tégly, na něž nasedaly říční štěrky.

Záchranný archeologický výzkum byl jedním z největších archeologických odkryvů v rámci historického jádra Králova Pole (plošně větší odkryvy byly uskutečněny pouze v areálu bývalého kartuziánského kláštera a jeho hospodářského zázemí, nacházejícího se poněkud severněji). Mojmírovo náměstí zachovává dodnes ve svém půdoryse stř̌edověkou náves významné brněnské předměstské vsi Králova Pole (obr. 1). Výzkum přinesl zásadní poznatky o vývoji dvou jeho usedlostí ve středověku a raném novověku. Podobu písemně doloženého osídlení Králova Pole v první polovině 13. století se výzkumem zjistit nepodařilo. I když sporadické doklady naznačují lidskou prítomnost na parcelách již v tomto období, pevnější struktura zástavby parcel a pravidelné půdorysy nadzemních i zahloubených částí dřevohliněných staveb byly doloženy až od druhé poloviny 13. století. V čelní části parcel byly zachyceny pozůstatky po sloupových nadzemních stavbách, fragmenty jejich hliněných podlah, výkopy dřevohliněných suterénů a velké množství ve spraši tesaných podzemních lochů. V této fázi osídlení nacházíme jak při uliční frontě, tak i v zázemí parcel zásobní jámy. Doklady dřevohliněné zástavby obdobného charakteru pokračují i ve 14. a 15. století. Zásadním impulsem pro další rozvoj Králova Pole bylo jistě založení kartuziánského kláštera markrabětem Janem Jindřichem v místech jeho staršího venkovského sídla v poslední třetině 14. století. Sloupové konstrukce staveb, reprezentované nálezy sloupových jam i žlabů, byly identifikovány i nad zánikovými zásypy sklepů a lochů z 15 . století a dokládají využivání tohoto typu konstrukce i na přelomu středověku a raného novověku. Na ploše výzkumu bylo zachyceno rovněž velké množství aktivit z období raného novověku (16.-18. století). Jednalo se opět především o sklípky, at' již kopané do podloží, nebo zděné ze smíšeného a později cihlového zdiva, odpadní jámy a jímky, hnojiště a jámy neznámého účelu. Nejpozději v průběhu novověku byly v zázemí parcel vybudovány také dvě nebo tři kamenné studny, které se nacházely výhradně při parcelních hranicích usedlostí. Kamenné stavby v podobě základů do návsi okapově orientovaných domů s dvorním prŕstavkem jsou pravděpodobně až aktivitou 17. nebo 18. století (Kolařík 2014).

\section{Metodika}

Základním úkolem archeologického výzkumu byla exkavace a dokumentace archeologických situací ohrožených novou výstavbou. K tomuto účelu bylo navrženo celkem pět sond, které se soustředily především na totální výzkum západní části staveniště, kde byla důvodně předpokládána př́itomnost pozůstatků zástavby středověkého a raně novověkého Králova Pole (obr. 2).

Výzkum byl zahájen v březnu 2009 prostřednictvím sond S01 a S02. Ty byly provedeny jako zjištovací a měly za úkol určit další strategii výzkumu. Sonda S01 se nacházela při uliční čáře Mojmírova náměstí, v severozápadním rohu staveniště. Po strojním odstranění recentních komunikačních vrstev a navážek bylo přikročeno k plošné exkavaci prostoru sondy. Menší zjištovací sonda $\mathrm{S} 02$ byla naopak položena na východní straně staveniště při Košinově ulici. V rámci ní byl $\mathrm{v}$ dílčích sondách postupně snížen terén po umělých vrstvách (ca $0,25 \mathrm{~m})$ až na úroveň sprašového podloží z období posledního glaciálu. V měsících dubnu a květnu 2009 výzkum pokračoval výkopem sondy S03, která se opět nacházela při uliční frontě Mojmírova náměstí, tentokrát v jihozápadním rohu staveniště. V červnu a červenci 2009 došlo k exkavaci sondy S04, která na východě bezprostředně navazovala na sondu S03 a svou východní stranou dosahovala téměř do poloviny stavební parcely. V srpnu a záŕí 2009 došlo k výkopu sondy S05. Ta se nacházela jednak mezi sondami S01 a S03, dále pak na východě navazovala na sondu S01 a na jihu sousedila se sondou S04, se kterou měly přibližně totožné úrovně východních stran. Zbývající část plochy staveniště byla v březnu roku 2013, kdy došlo k bagrování stavební jámy, pod odborným dohledem.

$\mathrm{K}$ nejstarším a zároveň nejvýraznějším dokladům pravidelné zástavby zkoumaných parcel náležel v sondě S03 odkrytý dřevohliněný suterén/sklípek s. j. 607 (obr. 2-5), jehož výplň je 


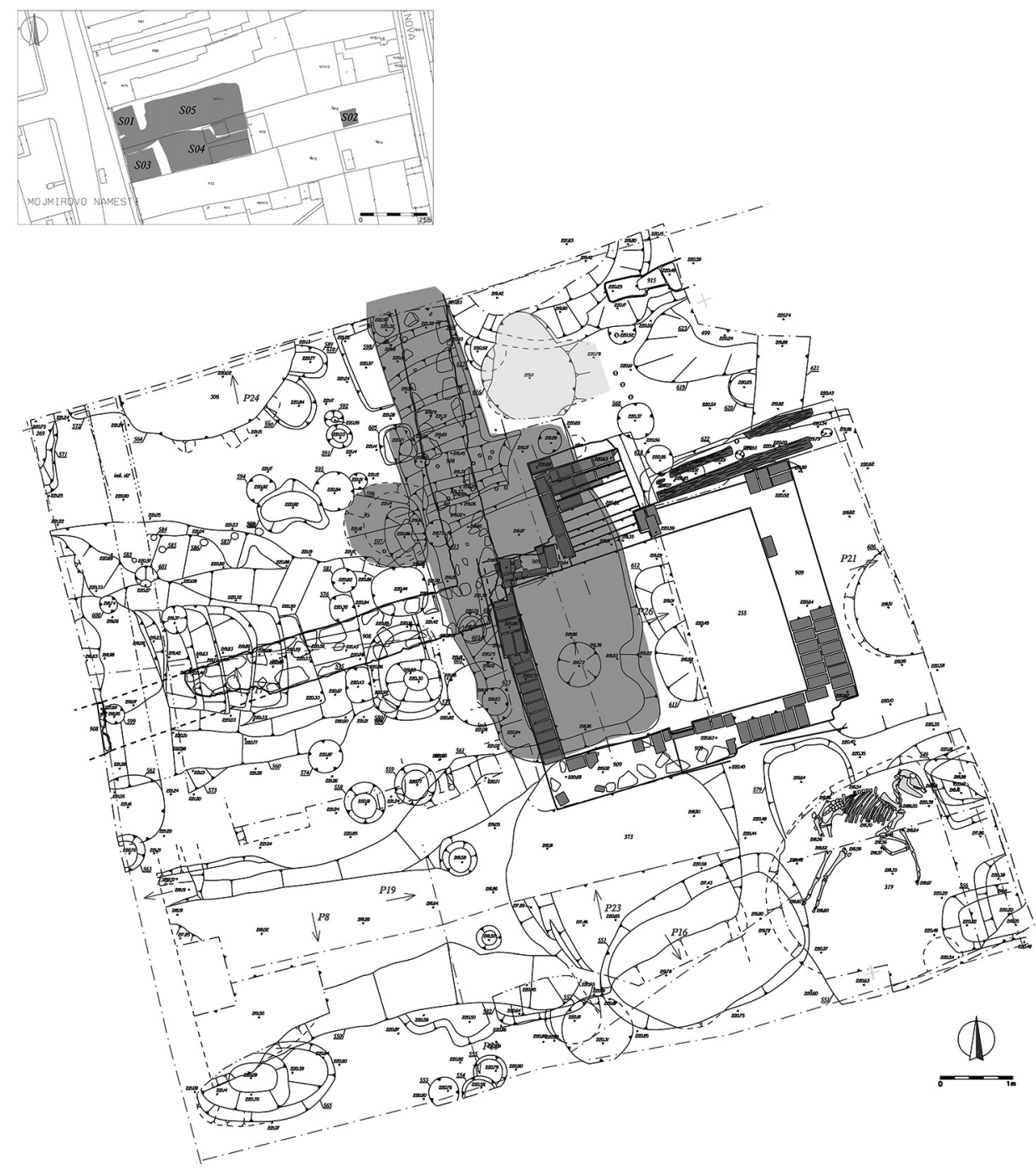

Obr. 2. Půdorys sondy S03 se zkoumanými objekty a vyznačeným sklípkem s. j. 607 - šedě podbarveno.

Abb. 2. Grundriss von Sondierschnitt S03 mit untersuchten Objekten und gekennzeichnetem Keller stratigraphische Einheit 607 - grau unterlegt.

tématem předkládané studie. Z podlahových úrovní s. j. 400 byl na profilu P25 odebrán vzorek na mikromorfologii o rozměrech ca $20 \times 5 \mathrm{~cm}$ (obr. 3). Jeho svrchní část tvoří výplň suterénu s. j. 399 (C), střední vlastní podlaha s. j. 400 (B) a bázi představuje sprašové podloží s. j. 100 (A). Tento blok byl v celku vysušen, impregnován pryskyřicí a rozříznut na tři díly, ze kterých byly následně vytvořeny výbrusy o rozměrech ca $7 \times 5 \mathrm{~cm}$. Tyto byly vytvořeny na Univerzitě v Gentu v Belgii. Výbrusy o mocnosti zhruba 30 mikrometrů byly studovány v binokulárním mikroskopu při zvětšeních 2-8× a v polarizačním mikroskopu při zvětšeních $8-800 \times$. 


\section{Výsledky}

\subsection{Archeologický kontext}

Suterén kopaný do podložní spraše s. j. 100 byl přibližně obdélného půdorysu o rozměrech 4,5 × 2,7 m a maximální dokumentované míře zahloubení 2,15 m (povrch 221,09 m n. m.) (obr. 3-5). Delší osou byl orientován rovnoběžně s průběhem dnešní uliční fronty, tedy ve směru SSZ-JJV. Západní stěna výkopu suterénu byla od dnešní uliční fronty vzdálena asi $5,5 \mathrm{~m}$. Východní část objektu byla výrazně narušena $\mathrm{v} 19$. nebo $\mathrm{v}$ první polovině 20. století stavbou cihlového sklípku s. j. 909. Stěny suterénu s. j. 607 byly pravidelné, př́ímé, svislé a dno až na níže popsané výjimky ploché a vodorovné. Ze severozápadního rohu suterénu vybíhal obdélný výkop stupňovité vstupní šije $(>2,16 \times 1,10)$, orientovaný k severoseverozápadu. V šíji bylo zachyceno šest stupňủ vytesaných ve sprašovém podloží, další dva se pak nacházely již v prostoru samotného suterénu. Severní část dna suterénu byla při schodišti oproti jeho jižněji se nacházející úrovni vyvýššna. V nižší části vstupní šíje byly při jednotlivých stupních patrné drobné kủlové jamky, které nepochybně sloužily jako opora pro dřevěné desky zajišt'ující stabilitu spodní části schodiště. V severozápadním rohu suterénu, na styku se vstupní šíjí, byla zachycena drobnější sloupová jáma, která mohla být součástí dveří otvíraných do interiéru. Přibližně ve stejném místě byl asi $0,6 \mathrm{~m}$ nad podlahou vytesán do západní stěny výkopu s. j. 607 otvor přibližně kruhového půdorysu o průměru 1,1 m a výšce asi $0,8 \mathrm{~m}$. Na jeho dně byly patrné drobné, do hnědočervena vypálené skvrny. Funkce tohoto poměrně rozměrného výklenku nám není jasná. Snad se mohlo jednat o odkládací niku. Malá odkládací nika byla vytesána i ve východní stěně při severovýchodním rohu suterénu.

Nejasný je rovněž vztah suterénu s výkopem s. j. 616 (obr. 2). V rámci exkavace se nepodařilo odlišit výplně obou objektů, a není tak vyloučeno, že oba jsou současné, respektive spolu funkčně souvisejí. Na to by mohla ukazovat shodná výška den obou výkopů. Podlahová úroveň v objektu 616 však nebyla zachycena. V kolizi s prŕípadným vstupem do objektu s. j. 616 je sice sloupová jáma v severovýchodním rohu suterénu, ale ta již v době hloubení výkopu s. j. 616 nemusela být funkční, nebo právě v souvislosti s ním svou funkci ztratila.

Při západní stěně byly ve dně suterénu dokumentovány tři sloupové jámy (s. j. 613-615), které byly nepochybně součástí nosné konstrukce obvodových stěn. Obdobná sloupová jáma se nacházela i v severovýchodním rohu objektu. Mezi jihozápadním rohem suterénu a sloupovou jámou s. j. 614 se podél jeho západní stěny nacházela, vytesaná ve sprašovém podloží, asi $0,5 \mathrm{~m}$ široká lavice, která převyšovala úroveň dna asi o $10 \mathrm{až} 15 \mathrm{~cm}$. V jižní části dna výkopu byla rovněž dokumentována mělká mísovitá prohlubeň nejasného účelu. 


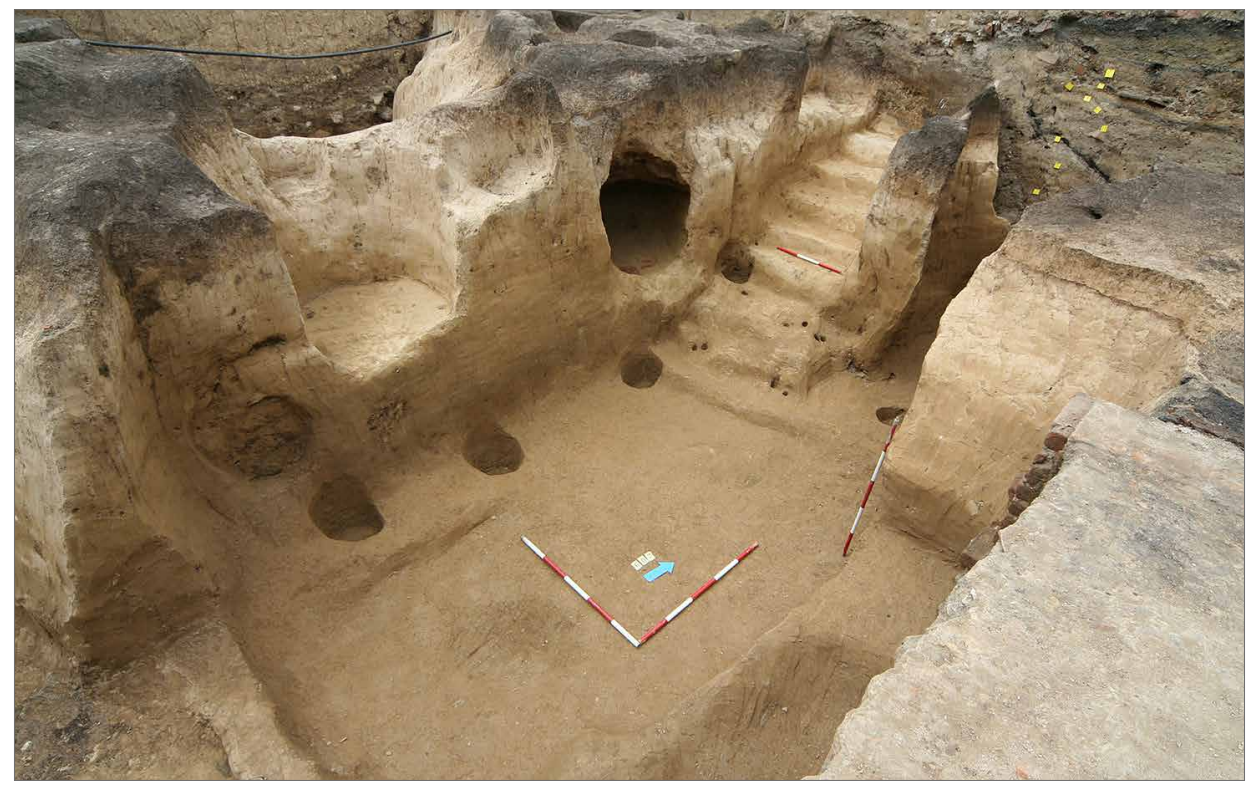

Obr. 4. Pohled do interiéru sklípku s. j. 607 od jihovýchodu. Zdroj archiv Archaia Brno z. ú.

Abb. 4. Blick ins Innere von Keller stratigraphische Einheit 607 von Südosten. Quelle Archiv Archaia Brno eingetragenes Institut.

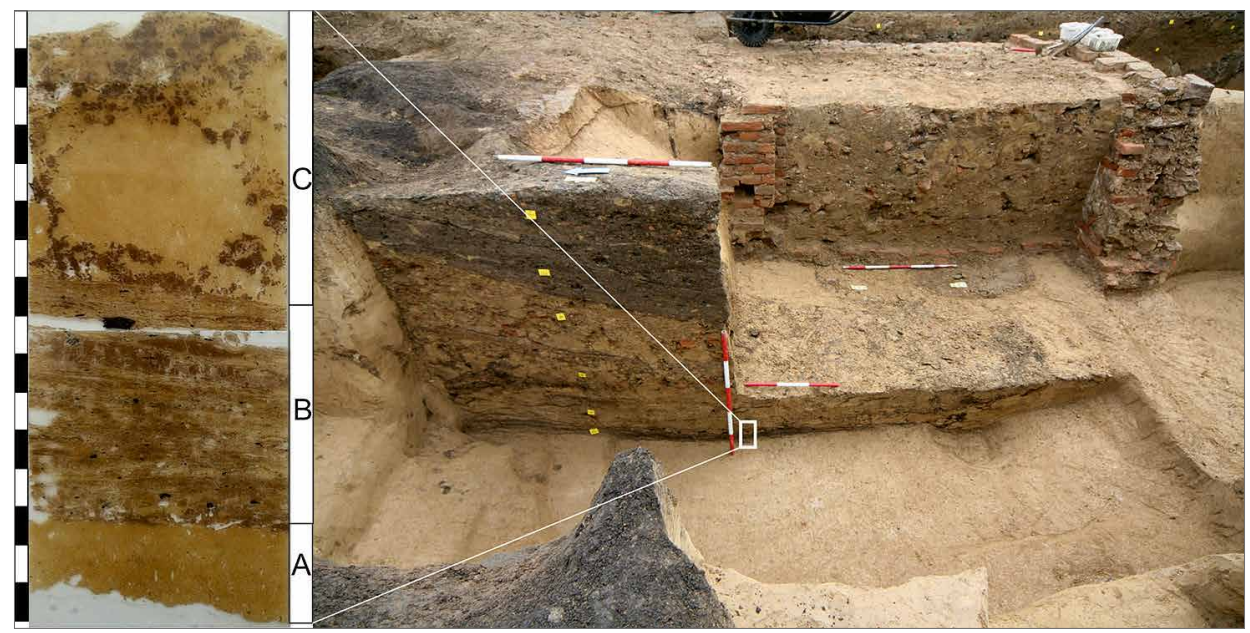

Obr. 5. Pohled na řez sklípkem s. j. 607 od západu. Šedá vrstva při dně výkopu představuje zkoumaný podlahový horizont; zdroj archiv Archaia Brno z. ú.; v levé části obrázku je sken výbrusu s cm škálou a vyznačenými faciemi A, B a C.

Abb. 5. Blick auf den Schnitt durch den Keller stratigraphische Einheit 607 von Westen. Die graue Schicht am Boden des Aushubs stellt den untersuchten Fußbodenhorizont dar; Quelle Archiv Archaia Brno eingetragenes Institut; im linken Bildteil Scan des Schliffs mit cm-Skala und gekennzeichneten Fazies A, B und C.

Zatímco šedě zbarvené svrchní části výplně suterénu (s. j. 381, 382) měly charakter druhotně přenesených uloženin, které sloužily k dorovnání částečně již zasypaného výkopu, světle žluté výplně v jejich podloží s. j. 383, 384 a 399 mohou být snad částečně původem z konstrukce suterénu, respektive $\mathrm{z}$ konstrukce nadzemní části př́ílušného domu. V jejich obsahu výrazně 
dominovaly zlomky nevypálené mazanice. Větší část výplně suterénu tak pravděpodobně tvoří destrukce jeho vlastních stěn, prrípadně stěn s ním souvisejícího domu.

$\mathrm{Na}$ dně výkopu se nacházelo zvrstvené podlahové souvrství s. j. 400 (obr. 3, 5). V terénu se makroskopicky jevilo jako tmavá hnědošedá tvrdá plastická hlína s přítomností velmi malých zlomků uhlíků, proložená méně výraznými mikrovrstvami béžových prachovitých sedimentů. Podlahové souvrství dosahovalo na profilu P25 maximální výšky $13 \mathrm{~cm}$. Směrem od vstupní šíje k jihu se jeho mocnost zmenšovala natolik, že při jižní straně sklípku již nebylo patrné.

Zánik suterénu klademe na základě nálezů z jeho výplně do první poloviny 14 . století. Dobu vzniku je vzhledem k chybějícím superpozicím s případnými staršími objekty možné jen předpokládat někdy ve druhé polovině 13. století. Starší datování vzniku sklípku není pravděpodobné $\mathrm{s}$ ohledem na celkový kontext $\mathrm{v}$ rámci zkoumaných parcel, kdy osídlení z první poloviny 13. století je zastoupeno pouze sporadicky, respektive v nejbližším okolí suterénu vůbec. Rovněž inventář mladších objektů neobsahuje druhotně uloženou starší nálezovou složku, což bývá v př́ípadě přítomnosti staršího osídlení na jiných lokalitách typické.

\subsection{Mikromorfologická charakteristika odebraných vzorků}

Makroskopicky lze studovaný výbrus rozdělit na tři vrstvy. Vrstvu A tvoří podložní spraš, B je jemně laminovaná vrstva o mocnosti ca $7 \mathrm{~cm}$. Mocnost jednotlivých laminek je variabilní a pohybuje se $\mathrm{v}$ rádech milimetrů. Vrstva je interpretována jako podlaha objektu. Třetí vrstva označená jako $\mathrm{C}$ je tvořena dvěma sedimentárními subfaciemi, které jsou do sebe namixovány, a je interpretována jako zásyp. Přechody mezi vrstvami jsou vždy ostré.

\subsubsection{A-podložní spraš}

Mikrostruktura vzorku je kombinovaná (obr. 6). Hlavním typem dobře vyvinutých pórů jsou kanálky a dutiny (př́čné průřezy kanálků), plocha vrstvy je však postižena četnými stopami po lezení mikrofauny, proto jsou zde vyvinuty také meziagregátové póry (obr. 6). Materiál vrstvy je vytříděný, prachovitojílovitý, $\mathrm{C} / \mathrm{F}(50 \mu \mathrm{m})=40: 60$. Hlavní typy minerálů jsou poloostrohranný křemen, živec a slída, v menší míře potom opakní minerály. Místy se vyskytuje sparitický karbonát jako pozůstatek po kořenových pseudomorfózách. Matrix má světle hnědou barvu, dvojlom je krystalický. Organická hmota je zachována ve formě rozložené jemnozrnné černé hmoty, rovnoměrně rozložené v ploše vrstvy. Mikrouhlíky nebyly identifikovány. Pedogenními prvky jsou již zmiňovaný sparitický karbonát, dále místy impregnace mikritickým karbonátem. Četné jsou náteky mikritického karbonátu na okraje pórů zasahující do okolní matrix (hypocoating). Relativně četné jsou lokální impregnace až náznaky vzniku dendritických nodulí složených $\mathrm{z}$ hydroxidů Fe a Mn. Pedogenním prvkem je rovněž kořenová bioturbace projevující se vznikem kanálků a dutin kruhového průřezu a intenzivní přítomnost stop po lezení. Zde však není zřetelné propojení těchto stop s nadložní vrstvou, tzn. tyto stopy po lezení vznikaly ještě před vznikem studovaného objektu.

\subsubsection{B-jemně laminovaná vrstva}

Mikrostruktura této části vzorku má obecně planární mikrostrukturu (obr. 7), přičemž v rámci jednotlivých lamin může převažovat masivní nebo kombinovaná mikrostruktura. Převažujícím typem pórů jsou planární póry a dále meziagregátové póry a dutiny nepravidelného tvaru. Materiál vrstvy je místy zřetelně usměrněný, středně až dobře vytříděný, prachovitojílovitý až prachovitopísčitý, C/F $(50 \mu \mathrm{m})=40: 60$ až $60: 40$ podle složení jednotlivých lamin. Laminy do sebe mnohdy neznatelně přecházejí, proto je obtížné vyčleňovat je jednotlivě. Mineralogické složení této vrstvy představuje převážně polozaoblený křemen, živec a slída, méně pak opakní minerály, přičemž místy se objevují poloostrohranné klasty křemene nebo rozvětralého živce. 


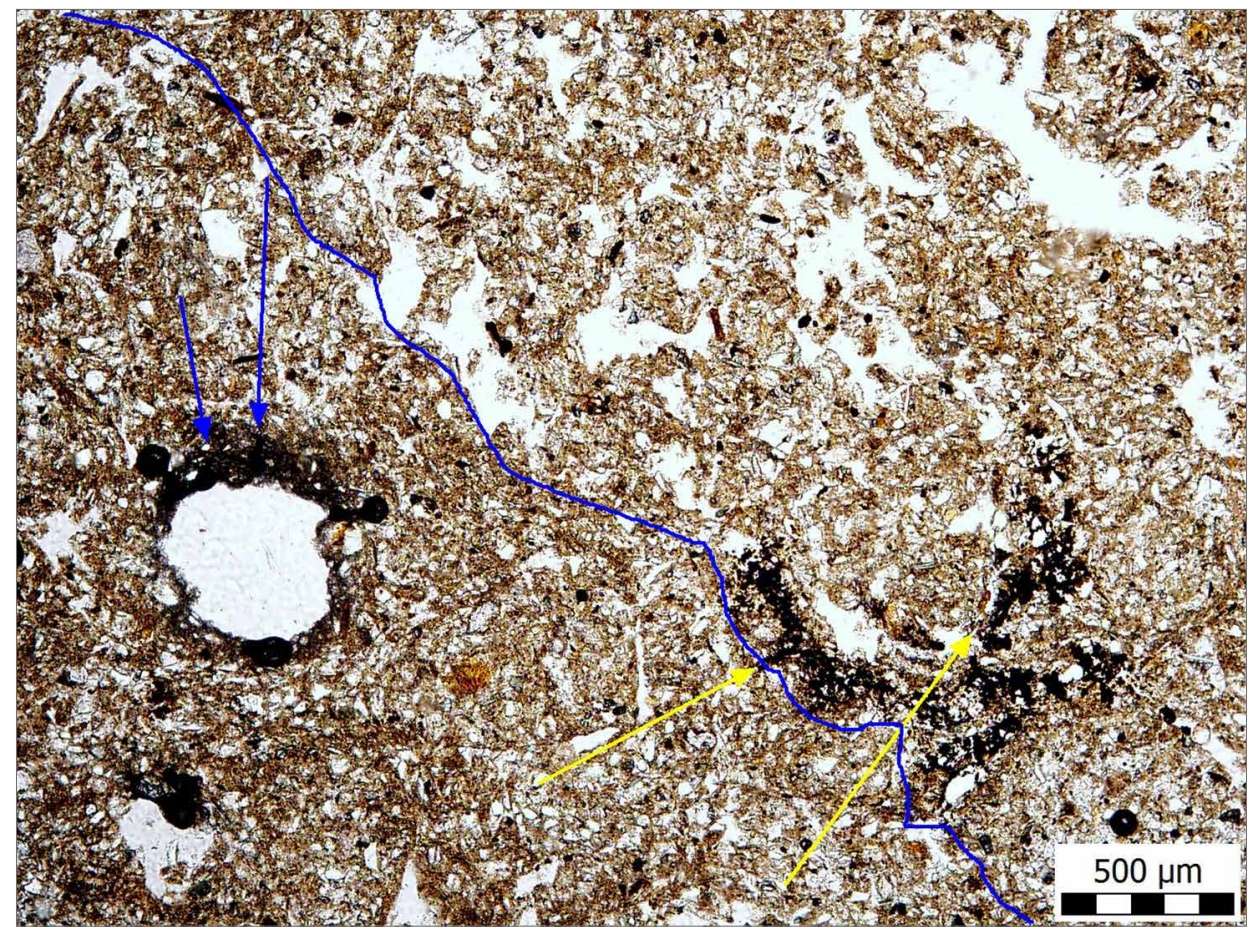

Obr. 6. Sprašové podloží studovaného objektu vykazující kombinovanou mikrostrukturu. Modrá linka označuje hranu stopy po lezení mikrofauny (pravá horní část vzorku); modré šipky ukazují na tzv. hypocoating, tj. na karbonáty bohatou impregnaci okolo vnitřního okraje póru, zasahující do okolní matrix. Tento pór vznikl kořenovou bioturbací. Kořeny rostliny přijímaly z okolí živiny a vlhkost, čímž podmínily přesun $\mathrm{CaCO}_{3}$ na okraj vznikajícího póru; žluté šipky ukazují na impregnaci hydroxidy Fe a Mn. Ta vzniká při měnících se oxidačně redukčních podmínkách. Foceno ve světle procházejícím přes jeden nikol (PPL). Foto L. Lisá.

Abb. 6. Eine kombinierte Mikrostruktur aufweisender Lössunterboden des untersuchten Objektes. Die blaue Linie kennzeichnet den Rand von Kriechspuren (rechter oberer Teil der Probe); die blauen Pfeile deuten auf sog. Hypocoatings hin, d.h. in die angrenzende Matrix reichende carbonatreiche Imprägnierungen um den Poreninnenrand. Diese Pore entstand durch Wurzel-Bioturbation. Die Wurzeln von Pflanzen bezogen aus der Umgebung Nährstoffe und Feuchtigkeit, wodurch sie eine Umlagerung von $\mathrm{CaCO}_{3}$ an den Rand der entstehenden Pore bewirkten; die gelben Pfeile zeigen auf Fe/Mn-Hydroxid-Imprägnierungen. Diese entstehen bei sich ändernden Oxidations-Reduktionsbedingungen. Fotografiert im Durchlichtmikroskop (PPL). Foto L. Lisá.

Ojediněle byl detekován sparitický karbonát. Barva matrix kolísá mezi světle až tmavě hnědou, opět podle barevných odstínů jednotlivých lamin. Dvojlom je krystalický.

Organická hmota je zastoupena pouze ojediněle částečně rozloženou hnědou organickou hmotou. Více je pak zastoupena rozložená organická hmota hnědé a černé barvy. Ve vzorku jsou výrazně zastoupeny mikrouhlíky, místy tvoří i vrstvy, přičemž první vrstva mikrouhlíků o mocnosti několika mikrometrů se objevuje přímo na bázi studované vrstvy (obr. 8 a 9). Díky zachovalým karbonátovým krystalům bylo možno v této vrstvičce kromě mikrouhlíků detekovat i popel (obr. 9). V matrix jsou nerovnoměrně rozmístěny občasné uhlíky nebo mikrouhlíky. Z dalších organominerálních součástí jsou zachovány v menší míře fytolity, nikoli však jako akumulace, které by indikovaly exkrementy, spíše ve formě artikulované po rozkladu organické hmoty na místě. Dále jsou místy zachovány fragmenty ostrohranných kostí a vaječných skořápek (obr. 10). Fekální sferulity, které by indikovaly přítomnost exkrementů, nebyly identifikovány.

Z pedogenních struktur jsou přítomny akumulace mikritického karbonátu ve formě místní impregnace, místy přítomnost $\mathrm{Fe} / \mathrm{Mn}$ nodulí nebo impregnací tvořených fosfáty. Ty často tvoří 


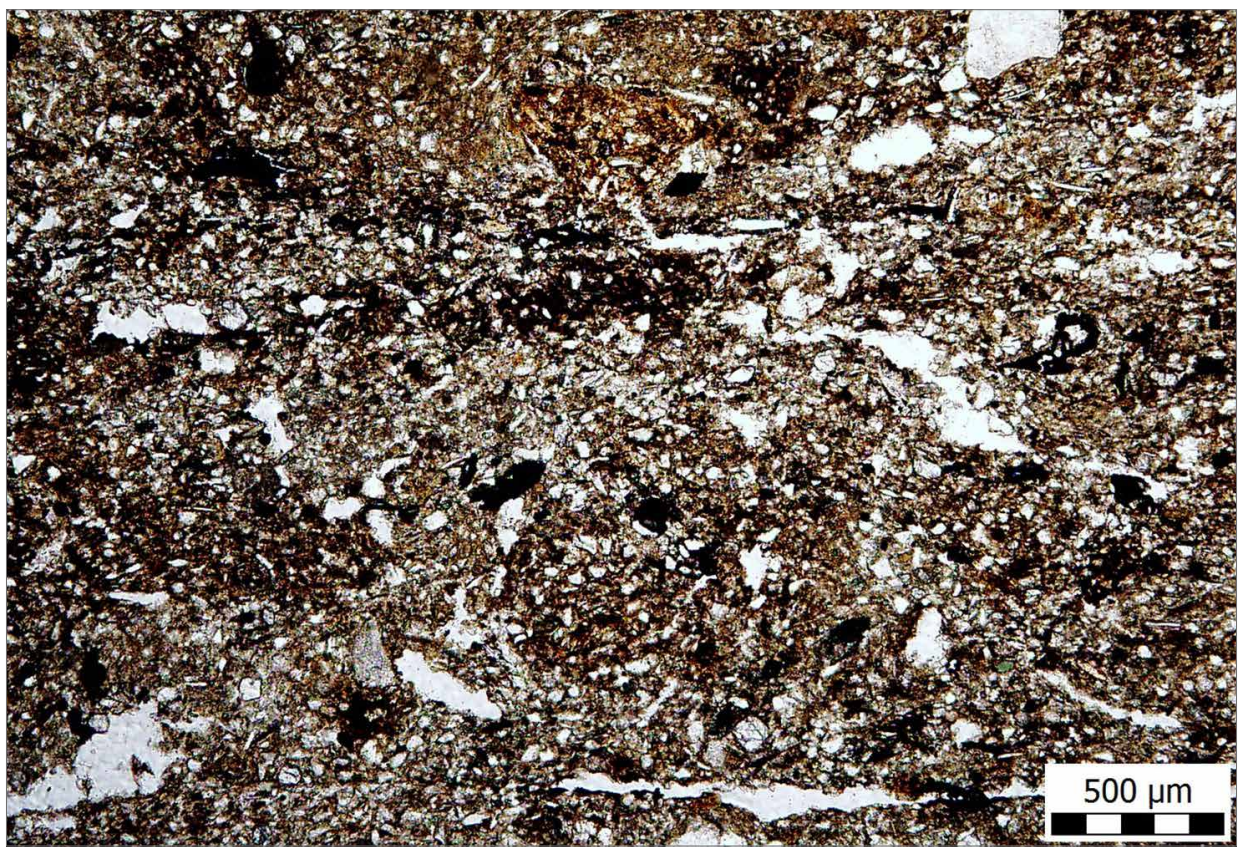

Obr. 7. Planární mikrostruktura vrstvy B. Přechody mezi jednotlivými laminami jsou nezřetelné (PPL). Foto L. Lisá.

Abb. 7. Planare Mikrostruktur von Schicht B. Die Übergänge zwischen den einzelnen Laminen sind undeutlich (PPL). Foto L. Lisá.

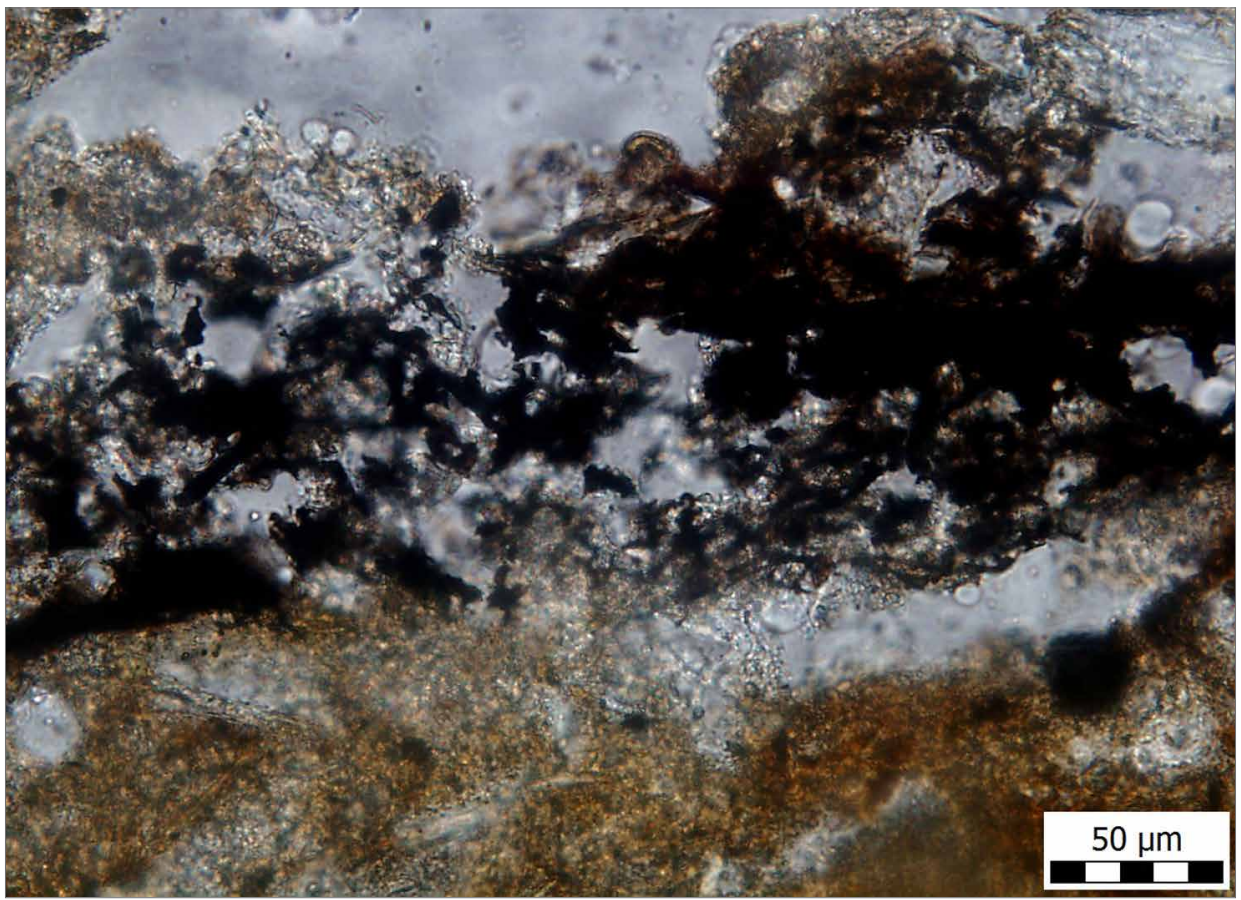

Obr. 8. Vrstva mikrouhlíků na bázi studované vrstvy B (PPL). Foto L. Lisá.

Abb. 8. Holzkohleschicht an der Basis der untersuchten Schicht B (PPL). Foto L. Lisá. 


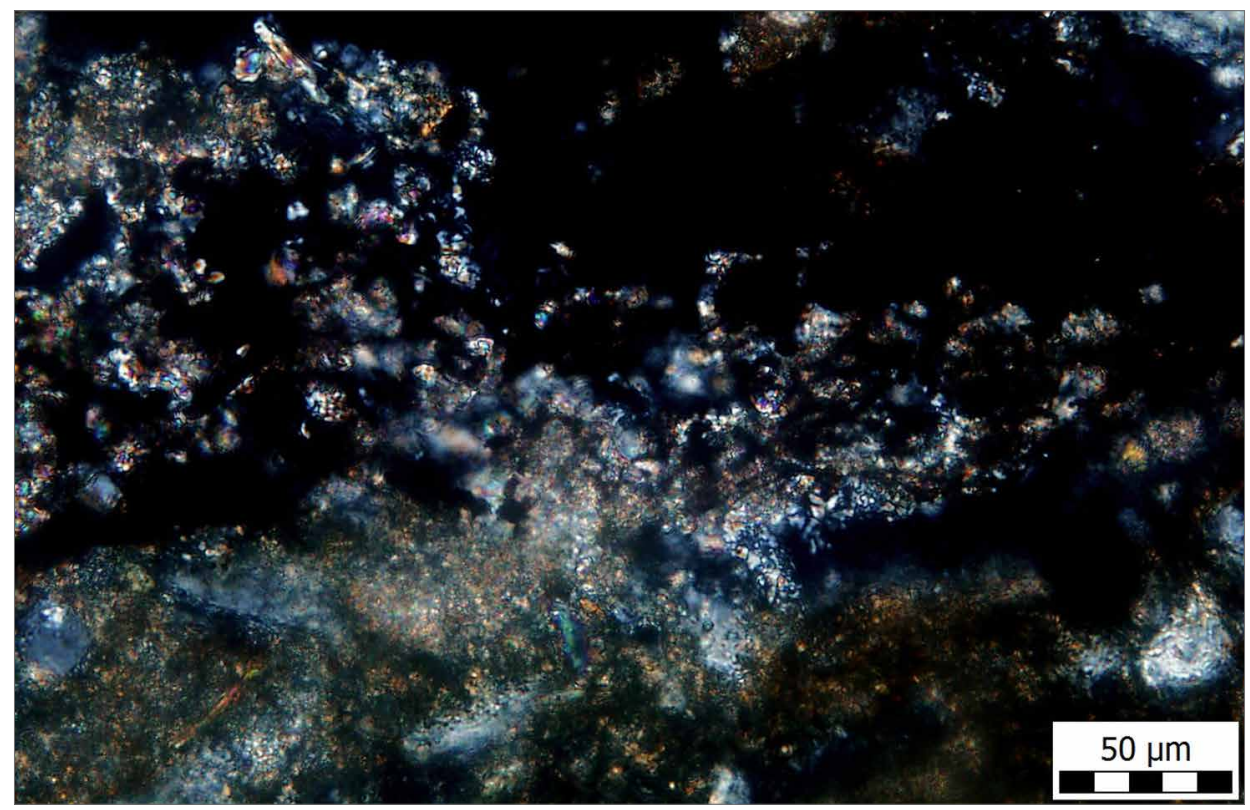

Obr. 9. Vrstva mikrouhlíků na bázi studované vrstvy B (PPL), srov. obr. 8. Snímek je tentokrát vyfocen ve světle procházejícím zkřiženými nikoly, aby vynikla př́ítomnost karbonátů indikující zachovaný popel. Foto L. Lisá.

Abb. 9. Mikroholzkohleschicht an der Basis der untersuchten Schicht B (PPL), vgl. Abb. 8. Die Aufnahme wurde diesmal mit gekreuzten Polarisatoren fotografiert, damit das Vorhandensein von erhalten gebliebener Asche indizierenden Carbonaten hervortritt. Foto L. Lisá.

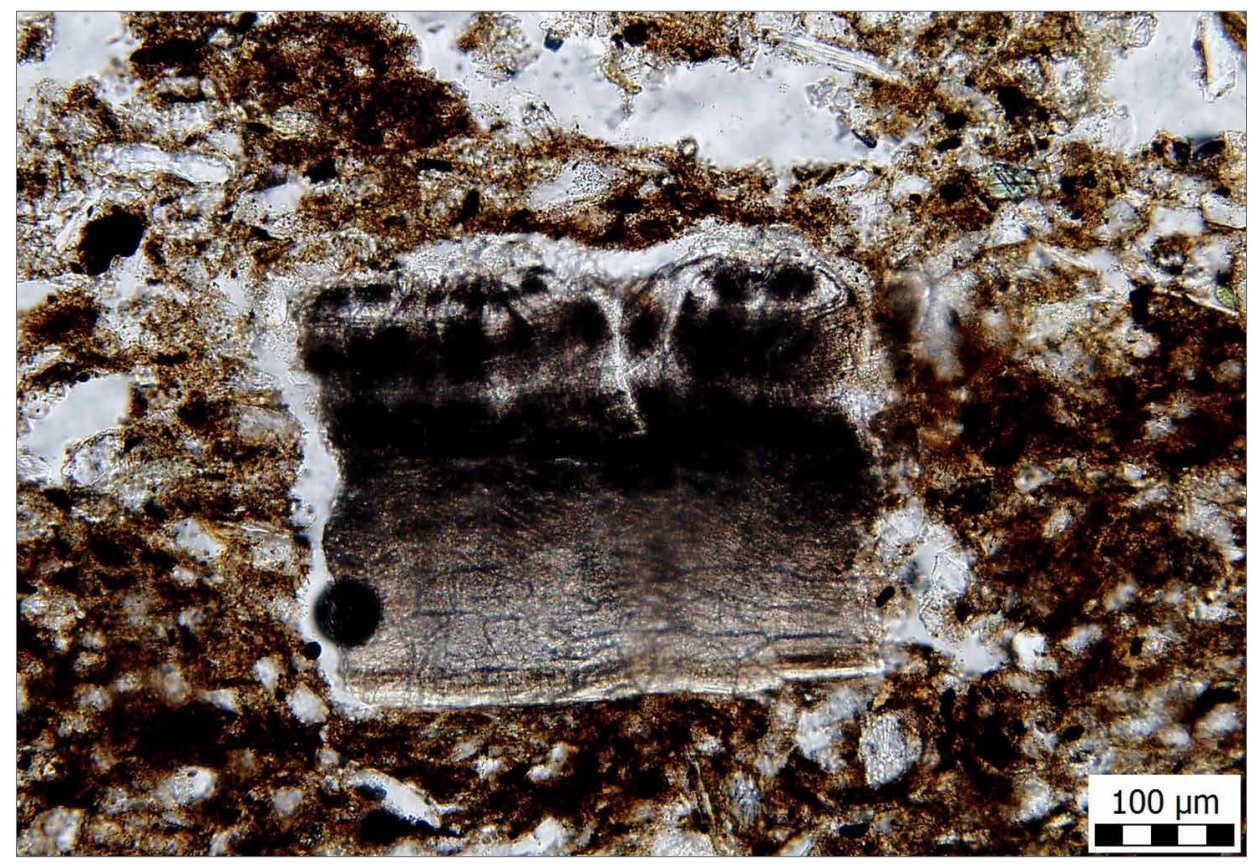

Obr. 10. Dobře zachovaný fragment skořápky vajička (PPL). Foto L. Lisá.

Abb. 10. Gut erhalten gebliebenes Eierschalenfragment (PPL). Foto L. Lisá. 
prachovité náteky indikující občasnou prosakující vodu. Přítomnost vlhkosti zároveň dokládají již zmiňované Fe/Mn nodule.

\subsubsection{C-zásyp}

Mikrostruktura vrstvy $\mathrm{C}$ je kombinovaná. Převažují zde póry typu puklin, př́ípadně meziagregátové póry či dutiny nepravidelného tvaru. Vrstva nenese známky usměrnění a je tvořena dvěma základními typy matrix. Ostrohranné až poloostrohranné klasty tmavě hnědé jílovitoprachovité matrix doslova plavou v jílovitoprachovité světlé matrix (obr. 11). Materiál této vrstvy je vytř́iěný a jeho $\mathrm{C} / \mathrm{F}(50 \mu \mathrm{m})=40: 60$. Mineralogicky je tvořen převážně poloostrohranným křemenem, živcem a slídou, $v$ malé míře potom opakními minerály. Místy byly detekovány sparitické karbonáty, které jsou přirozenou součástí podložních spraší. Barva tmavých agregátů je tmavě hnědá až černohnědá, barva světlé matrix je světle hnědá. Dvojlom je v obou prŕípadech krystalický. V části matrix se však objevují akumulace jílovité matrix, která má oranžovou barvu a striatický dvojlom.

Organická hmota je ve světlé části matrix identická s vrstvou A, tzn. jemnozrnná černá hmota, rovnoměrně rozložená v ploše vrstvy. Mikrouhlíky nebyly identifikovány. Pedogenní prvky jsou již zmiňovaný sparitický karbonát a dále místy impregnace mikritickým karbonátem.

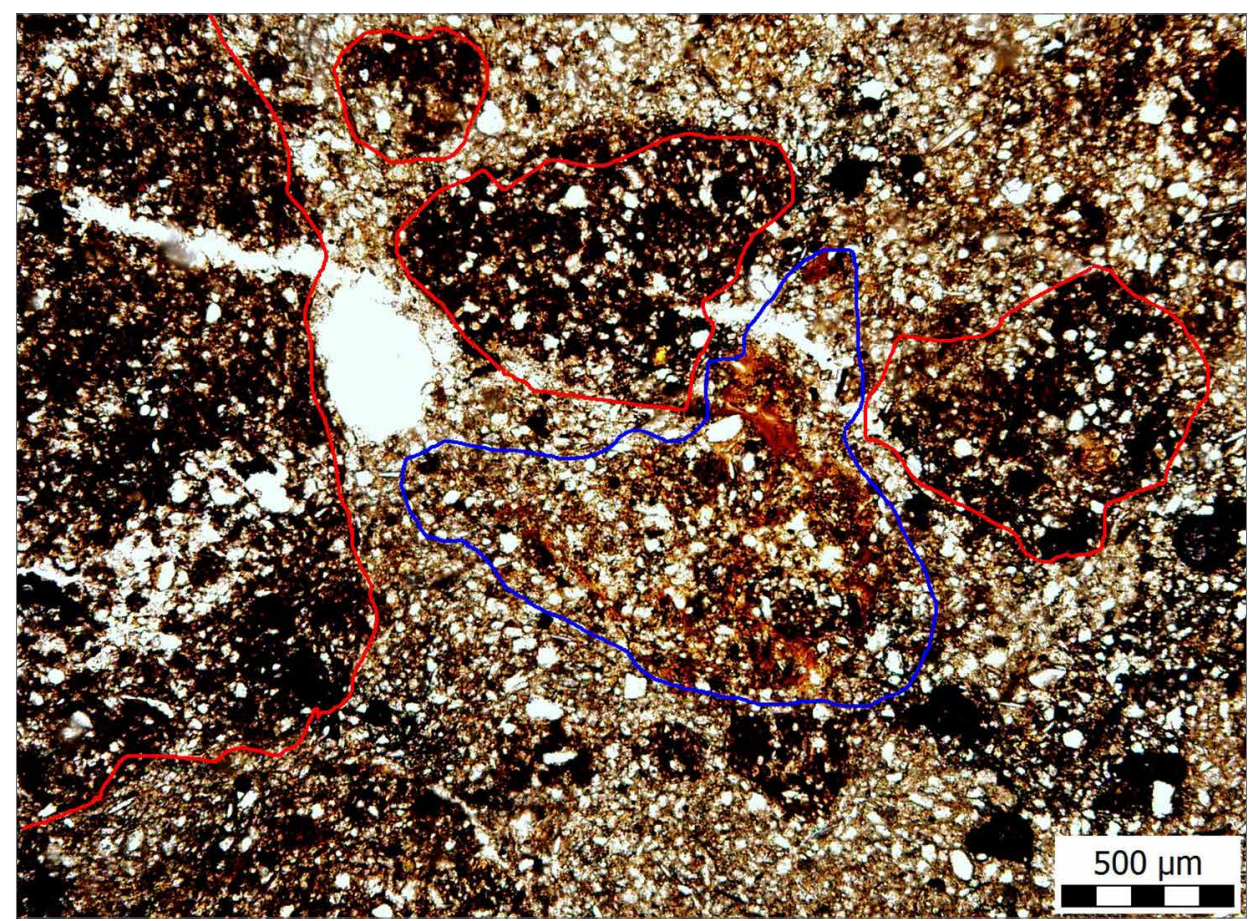

Obr. 11. Složení vrstvy $C$ je charakteristické přítomností světlé matrix typické svým složením pro spraš a tmavě hnědé matrix (červeně ohraničeno) typické svým složením pro A půdní horizont. Jsou zde však i známky přítomnosti jílových akumulací (modře ohraničeno), které mohou představovat cíleně připravenou část výmazu. Fragmenty jednotlivých typů matrix jsou ostrohranné, což svědčí pro relativně rychlé zasypání, resp. případnou destrukci okolních stěn nebo stropu (PPL). Foto L. Lisá.

Abb. 11. Die Zusammensetzung von Schicht $\mathrm{C}$ ist durch das Vorhandensein einer in ihrer Zusammensetzung für Löss typischen hellen Matrix (rot umgrenzt) und einer in ihrer Zusammensetzung für den Bodenhorizont A typischen dunkelbraunen Matrix charakteristisch. Es gibt hier jedoch auch Anzeichen für das Vorhandensein von Tonanhäufungen (blau umgrenzt), die einen gezielt vorbereiteten Teil einer Ausschmierung darstellen können. Die Fragmente der einzelnen Matrixtypen sind scharfkantig, was auf eine relativ schnell erfolgte Zuschüttung, bzw. auf eine eventuelle Zerstörung der angrenzenden Wände oder Decke hindeutet (PPL). Foto L. Lisá. 
Kanálky z původní struktury spraše (světlá matrix) jsou zaplněny jílovitoprachovitými náteky. Místy jsou zachovány $\mathrm{Fe} / \mathrm{Mn}$ nodule, které byly s největší pravděpodobností opět součástí původního sprašového materiálu. Naproti tomu tmavá část matrix (agregáty) obsahuje jemně rozptýlenou organickou hmotu, která spolu s hydroxidy železa materiál zabarvuje. Místy v ní byly detekovány i částečně rozložené útržky organické hmoty a velmi ojediněle i mikrouhlíky, z pedogenních struktur potom nolule Fe/Mn. Agregáty tmavé matrix často obsahují praskliny, které nejsou vyplněny jílovitoprachovitými náteky. Naopak prostor mezi tmavými agregáty a světlou matrix, respektive $\mathrm{v}$ rámci světlé matrix, obsahuje pukliny, které jsou vyplněny jílovitoprachovitými náteky. Důvodem této nerovnováhy je pravděpodobně jiná roztažnost tmavé matrix, která začala pukat až po vytvoření prachovitojílovitých náteků (při celkovém vysoušení). Dalším pedogenním prvkem, který je zachycen v rámci sledované vrstvy a který je antropogenního původu, je akumulace jílovité matrix (viz výše) obsahující striatické jílovité náteky (obr. 11).

\section{Diskuse}

\subsection{Funkce zahloubeného objektu v kontextu nadzemních prostor}

Z hlediska urbanistického se zdá pravděpodobné, že současná uliční čára Mojmírova náměstí byla vytyčena již v druhé polovině 13. nebo první polovině 14. století (Kolařík 2014). Orientace systému sloupových jam, žlabů, sklípků a lochů respektuje orientaci dnešní uliční čáry (obr. 2). $\mathrm{S}$ ohledem na absenci sloupových jam ve dně při východní stěně a vzhledem k menším rozměrům lze považovat za jednoznačné, že sklípek byl součástí domu sloupové konstrukce, jehož větší část byla nepodsklepena (Holub et al. 2005, 55). Přesný půdorys nelze ovšem jednoznačně identifikovat, především z důvodu nemožnosti přiřazení většiny sloupových jam v okolí sklípku ke konkrétním stavebním horizontům. Z orientace vstupní šíje vyplývá, že sklípek nebyl přístupný $\mathrm{z}$ veřejného prostoru návsi, ale bud' ze dvora usedlosti, jejího průjezdu, nebo z interiéru nadzemní části souvisejícího domu. Studovaný objekt tedy sloužil pravděpodobně jako chladný a tmavý skladovací prostor, určený pro uložení potravin a nápojů k denní spotřebě. V původní dispozici nadzemní části domu můžeme předpokládat blízkost kuchyně, respektive prostoru určeného k vaření (srov. Vařeka 2002, 271-272).

Dobu existence objektu nelze přesně určit, předpokládáme maximálně 100 let, spíše méně. Z nálezové situace uvažujeme o intencionálním zániku objektu (charakter zásypu), at' už jeho príćiny byly jakékoliv (přestavba domu?). Objekt nenese stopy požáru, spodní část výplně má charakter destrukce dřevohliněné stavby, snad domu souvisejícího se sklípkem (nevypálená mazanice, část přemístěné spraše může pocházet rovněž z výkopu mladších lochů v okolí sklípku). Horní část zásypu má charakter dorovnávky částečně zasypaného výkopu a je zjevné, že k zasypání sklípku došlo rychle a že na něj plynule navázala výstavba nové usedlosti nebo její přestavba.

\subsection{Mikromorfologická interpretace formačních procesů ve vztahu $k$ archeologickým interpretacím v širším kontextu}

Ze studovaného kontextu je zřejmé, že se v př́ípadě báze odebraného vzorku (A) jedná o spraš nebo o slabě vyvinutou půdu na spraši, částečně bioturbovanou a postiženou zvýšenými vlhkostními podmínkami. Bioturbace není spojena s vrstvou v nadloží, tj. se samotnou podlahou studovaného objektu. Na ni nasedající vrstva B představuje upravovanou pochozí část objektu, která vznikala našlapáváním minerální matrix, organické hmoty a organominerálního odpadu. Př́itomnost jednotlivých lamin je důsledkem jednotlivých událostí během roku, kdy byl z vnějšku na podrážkách bot přinášen různý materiál, a to v odlišné intenzitě (mokro/sucho). Tomu odpovídá i makroskopické pozorování v terénu. Mocnost vrstvy od vstupu směrem do zadní části ubývá, a při jižní stěně již podlahová vrstva zachycena nebyla. Lze tedy předpokládat, že laminovaná vrstva vznikla postupným užíváním objektu, neustálým nanášením materiálu směrem od vchodu 
a jeho sešlapáváním. V prostoru schodnic byla situace obdobná, s tím rozdílem, že neustálým používáním v podstatě hliněných schodnic došlo $\mathrm{k}$ jejich destrukci. Postupným užíváním došlo k nánosu a sešlapání většího množství materiálu, takže schodištové stupně splynuly až téměř do podoby šikmé rampy. Vstup do sklípku musel být v pozdějších fázích reparován a za pomocí kolíků zde byly instalovány dřevěné schodnice. Mikromorfologické vzorky z prostoru schodů nebyly odebrány.

Zajímavý je však fakt, že jednotlivé minerální a organické součástky jsou horizontálně uloženy. Usměrnění tohoto materiálu muselo vznikat cíleným zametáním a opakovaným tlakem z nadloží (zašlapáváním). Toto usměrnění může být částečně predisponováno tlakem, nicméně zametání jako takovému odpovídá i občasná přítomnost prachovitých náteků spolu s fosfatickou matrix. Intenzivní a opakovaný tlak z nadloží je promítnut do struktury vzorku také ve formě horizontálních pórů. Podobné struktury byly zachyceny v podlaze sklípku v Tišnově (Lisá-KolaříkBajer 2009). V prŕípadě tišnovského sklípku však nedocházelo k podlahovým úpravám a materiál, kterým je podlaha tvořena, vznikal pouze sešlapáváním, bez usměrnění a bez laminace. Některé z horizontálních pórů zachycených v podlaze sklípku v Králově Poli jsou zvýrazněny přítomností protáhlých úlomků organické hmoty. Doba, po kterou tento set mikrolamin vznikal, je závislá na intenzitě využivání dané prostory, proto je těžké ji odhadnout. Analogicky odpovídá však desítkám let, spíše několika generacím, to však za předpokladu, že způsob ošetřování povrchu a intenzita jeho využivání je konstantní (Lisá et al. 2020). Cílené dodávání (opravování) minerální hmoty v ploše (analogie líčení stěn) pravděpodobně probíhalo, není však zachováno ve formě poloh v řádu centimetrů. Materiál, který by byl lokálně použit na správku podlahy, je zabudován v popisovaném setu díky zametání a rozšlapávání a ve výsledku je zachován ve formě maximálně milimetrových průběžných lamin se špatně znatelnými přechody do nadloží a podloží. Proto také není zřejmé, že by do materiálu používaného na správku byla dodávána cíleně organická hmota, např́iklad ve formě hnoje, jako je tomu u recentních lokalit. Z archeologického hlediska však o cíleném opravování podlahové úrovně primárně nelze vůbec uvažovat, a to především vzhledem k prredpokládané funkci objektu. Dle archeologů nebylo potřeba povrch - na rozdíl od obytných částí domu, které se nacházely na povrchu terénu - upravovat.

Poslední ze zastižených facií, tj. facie $\mathrm{C}$, představuje zásyp, který vznikl bud'to intencionálně, nebo náhlou destrukcí stěn a okolí objektu, případně výmazu stěn nebo stropu. Mikrostrukturní analogií takového zásypu jsou naprríklad bazální části výplně prríkopů typu Spitzgraben (hrotovitý prríkop), kdy se do centra příkopu dostává materiál z jeho stěn a zároveň materiál z nejbližšího okolí, který je stále tvořen půdním A horizontem (Lisá et al. 2016). Nebyly zde indikovány sedimenty klasického sídlištního odpadu.

\section{Závěr}

Z archeologického hlediska lze námi posuzovaný objekt interpretovat jako drobný sklípek sloužící obyvatelům domu $\mathrm{k}$ uskladnění potravin a nápojů $\mathrm{k}$ denní spotřebě a $\mathrm{v}$ původním rozmístění aktivit lze předpokládat i blízkost kuchyně, respektive $\mathrm{v}$ této době spíše prostoru určeného $\mathrm{k}$ vaření.

Studovaný vzorek obsahuje na bázi sprašové podloží, na kterém vznikla postupným našlapáváním a cíleným zametáním podlahová vrstva. Vnitřní struktura podlahových vrstev naznačuje, že by se mohlo jednat o cíleně upravovanou a dlouhodobě používanou podlahu, a to $\mathrm{v}$ rámci desítek let nebo dvou až tř́i generací (nebo jednotek generací), podle toho jak intenzivně byla prostora využívána. Tato zjištění jsou částečně v rozporu s archeologickými představami, respektive se zažitými představami o možných způsobech úpravy takové prostory. Zatímco úprava vstupu byla díky sešlapávání víceméně nutná, a tedy pochopitelná, a především makroskopicky zdokumentovatelná, pro samotný prostor sklípku již tak zřejmé doklady nejsou. Z hlediska funkčního využití není úprava povrchu, navíc situovaného v tmavém prostoru nezbytná. Vnitřní struktura podlahových sedimentů přesto ukazuje na usměrnění, které vznikalo s největší pravděpodobností právě zametáním. Archeologické a mikromorfologické interpretace se tedy rozcházejí pouze ve 
způsobu úpravy. Zatímco z makroskopické dokumentace byla podlaha interpretována jako vzniklá postupným našlapáváním, mikromorfologická interpretace dodává, že jde o podlahu sklípku, který byl udržován v relativní čistotě a na jehož podlahu byl opakovaně našlapáván běžný odpad z činnosti domácnosti. Vrstva, která je nad pochozím horizontem, představuje zásyp, s největší pravděpodobností opad ze stěn zahloubeného objektu a okolního půdního horizontu A, prŕípadně výmazu nadzemních prvků.

Metoda mikromorfologie $\mathrm{v}$ archeologickém kontextu $\mathrm{v}$ tomto př́ípadě plně neodpověděla na způsob využití zahloubené prostory, přinesla však minimálně informaci o tom, jakým způsobem byla tato prostora udržována $\mathrm{v}$ čistotě a jak intenzivně byla používána.

Práce vznikla jako součást projektu Proměna městského domu ve 13. století (Brno-Praha-Wroclaw), grant GA ČR č. 17-23836S, a jako součást interního projektu Geologického ústavu AV ČR, v. v. i., RVO 67985831.

\section{Literatura}

BERAN, V. et al., 2013: Beran, V.-Hajnalová, M.-Kos, P.-Lisá, L.-Parma, D., Geoarcheologický výzkum raně středověké kovárny z Modřic u Brna, Živá archeologie 15, 25-31.

HOLUB, P. et al., 2005: Holub, P.-Kolařík, V.-Merta, D.-Peška, M.-Zapletalová, D.-Zůbek, A., Ke stavu poznání nezděné měšt’anské architektury vrcholně středověkého Brna, Forum urbes medii aevi 2, 44-101.

KARKANAS, P.-GOLDBERG, P., 2019: Reconstructing Archaeological Sites; Understanding the Geoarchaeological Matrix. Oxford: Wiley Blackwell.

KOLǍ̌ÍK, V., 2014: Brno, Královo Pole „Rezidence Mojmírovo náměstí“. Nálezová zpráva o provedení archeologického výzkumu č. j. 29/2014, ulož. v archivu Archaia Brno z. ú.

KUNA, M. et al., 2013: Kuna, M.-Hajnalová, M.-Kovačiková, L.-Lisá, L.-Novák, J.-Bureš, M.-Cílek, V.Hošek, J.-Kočár, P.-Maier, A.-Makowiecki, D.-Scott Cummings, L.-Sůvová, Z.-Světlík, I.-Vandenberghe, D.-Van Nieuland, J.-Yost, C.-Zabilska-Kunek, M., Raně středověký areál v Roztokách z pohledu ekofaktů, PA CIV, 59-147.

LISÁ, L.-KOLAŘÍK, V.-BAJER, A., 2009: The Geoarchaeological and Micromorphological Reconstruction of Medieval Food Store Room Floor Layers; the Case Study from Tišnov, Czech Republic, Frankfurter Geowissenschaftliche Arbeiten 30, Serie D, Archaeological Soil Micromorphology, 71-80.

LISÁ, L.-LISÝ, P., 2019: Podlaha jako experiment aneb vhled do životního rytmu našich předků, Živá archeologie 21, 3-7.

LISÁ, L. et al., 2015: Lisá, L.-Komoróczy, B.-Vlach, M.-Válek, D.-Bajer, A.-Kovárník, J.-Rajtár, J.-Hüssen, C. M.-Šumberová, R., How were the ditches filled? Sedimentological and micromorphological classification of formation processes within graben-like archaeological objects, Quaternary International $370,66-76$.

LISÁ, L. et al., 2017: Lisá, L.-Peška, M.-Merta, D.-Gregor, M., Maintenance of Underground Granaries in Medieval Towns; Case Study from Padowetz, Brno, Czech Republic, IANSA VIII, 157-165.

LISÁ, L. et al., 2020: Lisá L.-Staněk, P.-Zůbek A.-Nejman L., Floor Maintenance as a Possible Cultural Behavioural Status? Preliminary Interpretations of Floor Formation Processes from Medieval Brno, Czech Republic, IANSA XI, Online First.

LISÁ, L. et al., 2020a: Lisá, L.-Kočár, P.-Bajer, A.-Kočárová, R.-Syrová, Z.-Syrový J.-Porubčanová, M.Lisý, P.-Peška, M.-Ježková, M., The floor: a voice of human lifeways - a geo-ethnographical study of historical and recent floors at Dolní Němčí Mill, Czech Republic, Archaeological and Anthropological Sciences 112 (115). Dostupné z: https://link.springer.com/article/10.1007/s12520-020-01060-y.

MACPHAIL, R. I.-GOLDBERG, P., 2018: Applied Soils and Micromorphology in Archaeology. Cambridge Manuals in Archaeology. Cambridge University Press.

NICOSIA, C.-STOOPS, G., 2017: Archaeological Soil and Sediment Micromorphology. Oxford: Wiley Blackwell. 
NOVÁK, J. et al., 2012: Novák, J.-Lisá, L.-Pokorný, P.-Kuna, M., Charcoal analyses as an environmental tool for the study of Early Medieval sunken houses infills in Roztoky near Prague, Czech Republic, Journal of Archaeological Science 39, 808-817.

STOOPS, G., 2003: Guidelines for Analysis and Description of Soil and Regolith Thin Sections. Madison, Wisconsin, USA: Soil Science Society of America.

STOOPS, G.-MARCELINO, V.-MEES, F., 2010: Interpretation of Micromorphological Features of Soils and Regoliths. Amsterdam: Elseiver.

VAŘEKA, P., 2002: Zahloubené stavby v českých městech vrcholného středověku - zemnice nebo suterény nenalezených nadzemních domů? In: Archeologie nenalezeného. Sborník přátel, kolegů a žáků k životnímu jubileu Slavomila Vencla (Neustupný, E., ed.), 252-285. Plzeň.

\section{Zusammenfassung}

Vermag die Mikromorphologie im archäologischen Kontext auf die Frage der Nutzung von eingetieften Räumlichkeiten in einem mittelalterlichen Dorf eine Antwort zu liefern? Eine Beispielstudie Brünn - Königsfeld (Královo Pole)

Der hier vorgelegte Beitrag fasst die Problematik des Studiums von Fußbodenhorizonten bei eingetieften mittelalterlichen Objekten zusammen. Vorhergehende Studien dieses Typs waren in der Vergangenheit ausschließlich auf städtische Umgebungen ausgerichtet. In vorliegendem Fall wird ein Keller/Souterrain im Bereich des Intravillans des historischen Dorfes Königsfeld (Královo Pole, Dorfplatz auf dem Grundriss des heutigen Platzes Mojmírovo náměstí) beschrieben. Den Untergang des Souterrains legen wir aufgrund von Funden aus seiner Verfüllung in die erste Hälfte des 14. Jahrhunderts. Die Entstehungszeit kann im Hinblick auf fehlende Superpositionen mit eventuellen älteren Objekten nur irgendwann in der zweiten Hälfte des 13. Jahrhunderts vermutet werden. Die hier vorgelegte Studie versucht am Beispiel eines laminierten Gehhorizontes auf dem Boden dieses Kellers aufzuzeigen, welchen Charakter und welches Aussehen der potenzielle Fußbodenhorizont hat und wie er im gegebenen Kontext wahrscheinlich entstanden war. Gleichzeitig wird in der Studie die Sicht der Geländearchäologie im Vergleich mit den bisherigen Erkenntnissen der Mikromorphologie über das Informationspotenzial von Lehmfußböden diskutiert.

Aus archäologischer Sicht kann das von uns beurteilte Objekt als kleiner Keller interpretiert werden, der den Hausbewohnern zur Lagerung von Lebensmitteln und Getränken für den täglichen Bedarf diente, und bei der ursprünglichen Verteilung der Aktivitäten kann man auch die Nähe einer Küche, bzw. in jener Zeit eher eines zum Kochen bestimmten Raumes voraussetzen. Die untersuchte Probe enthält an der Basis einen Lössunterboden oder einen leicht auf Löss entwickelten Boden, der durch allmähliches Festtreten und gezieltes Kehren der Fußbodenschicht entstand. Die innere Struktur der Fußbodenschichten deutet an, dass es sich um einen gezielt hergerichteten und langfristig genutzten Fußboden handeln könnte, und zwar im Rahmen von Jahrzehnten oder Generationen, je nachdem wie intensiv die Räumlichkeit genutzt wurde. Diese Feststellungen stehen in einem relativen Widerspruch zu den archäologischen Vorstellungen. Im Kontext mit der archäologischen Interpretation handelt es sich also um den Fußboden eines Kellers, der jedoch zumindest relativ sauber gehalten wurde und in dessen Fußboden wiederholt üblicher Haushaltsabfall festgetreten wurde. Die sich über dem Gehhorizont befindende Schicht stellt eine Streuschicht dar, höchstwahrscheinlich abgelöste Bröckchen von den Wänden des eingetieften Objektes und des daran angrenzenden Bodenhorizontes A, ggf. einer Ausschmierung oberirdischer Elemente.

Die Methode der Mikromorphologie hat in vorliegendem Fall im archäologischen Kontext auf die Frage der Nutzung der eingetieften Räumlichkeit keine Antwort geliefert, jedoch gab sie zumindest Auskunft darüber, wie diese Räumlichkeit sauber gehalten und wie intensiv sie genutzt wurde. 
Die vorliegende Arbeit entstand als Teil des Förderprojektes Die Wandlung des Stadthauses im 13. Jahrhundert (Brünn-Prag-Breslau) GA ČR Nr. 17-23836S und als Bestandteil des internen Projektes des Geologischen Instituts der Akademie der Wissenschaften der Tschechischen Republik RVO 67985831.

doc. Mgr. Lenka Lisá, Ph.D., Geologický ústav AV ČR, v. v. i., Rozvojová 269, 16500 Praha, Česká republika, lisa@gli.cas.cz

Mgr. Václav Kolařík, Archaia Brno z. ú., Bezručova 15/78, 60200 Brno, Česká republika, vkolarik@archaiabno.cz 